Article

\title{
Seed Germination of Sunflower as a Case Study for the Risk Assessment and Management of Transgenic Plants Used for Environmental Remediation in South Korea
}

\author{
Kyong-Hee Nam ${ }^{*}{ }^{\dagger}$ and Sung Min Han ${ }^{\dagger}$ \\ Division of Ecological Safety, National Institute of Ecology, Seocheon 33657, Korea; smhan@nie.re.kr \\ * Correspondence: khnam@nie.re.kr; Tel.: +82-41-950-5823 \\ + Both authors contributed equally to this work.
}

Received: 17 November 2020; Accepted: 2 December 2020; Published: 3 December 2020

\begin{abstract}
In South Korea, the safety management of living modified organisms (LMOs) is regulated by seven government agencies depending on their use, and the Ministry of Environment is in charge of LMOs to manage environmental remediation and effects on natural ecosystems. This study aimed to develop appropriate research tools to determine the factors affecting the invasiveness of transgenic plants used for environmental remediation. We examined the persistence of sunflower (Helianthus annuus L.) as a candidate by comparing the seed viability at different controlled temperatures and soil depths (ranging from 0 to $30 \mathrm{~cm}$ ). The germination characteristics of seeds significantly differed between cultivars and temperatures. The field trials indicated that seeds buried at a depth of $30 \mathrm{~cm}$ mostly decayed within three weeks, whereas those buried at $0 \mathrm{~cm}$ persisted for eight weeks but decayed after sixteen weeks, implying a significant interaction between burial depth and seed persistence. At all soil depths, no dormant seeds were detected over one week after burial. These results suggest that sunflower seeds could not be successfully established under our experimental conditions. Since seeds on the soil surface demonstrated the highest rates of germination, such seeds may require particularly careful management to prevent unintended effects on ecosystems.
\end{abstract}

Keywords: environmental remediation; invasiveness; persistence; seed burial; soil seed bank; sunflower; transgenic plant

\section{Introduction}

With advances in modern biotechnology, numerous living modified organisms (LMOs) with improved traits have been developed, but their potential risks to human health and the environment remain controversial [1]. Accordingly, to prevent the risks of LMOs to public health and to preserve and sustain the use of biological diversity, the Cartagena Protocol on Biosafety (CPB) to the Convention on Biological Diversity has developed an international standard for a minimum set of requirements for the safe transfer, handling, and use of LMOs [2]. In South Korea, the Transboundary Movement, Etc. of LMOs Act (hereinafter, the LMOs Act), which is a domestic measure to implement the CPB, was enacted in March 2001 and took effect in January 2008 [3]. The LMOs Act regulates the safety management of LMOs by seven government agencies according to the use of LMOs, and the Ministry of Environment (MOE) specializes in the development, production, import, export, distribution, and use of LMOs for environmental remediation (Figure 1). Furthermore, the MOE is responsible for the risk review of LMOs in natural ecosystems. 


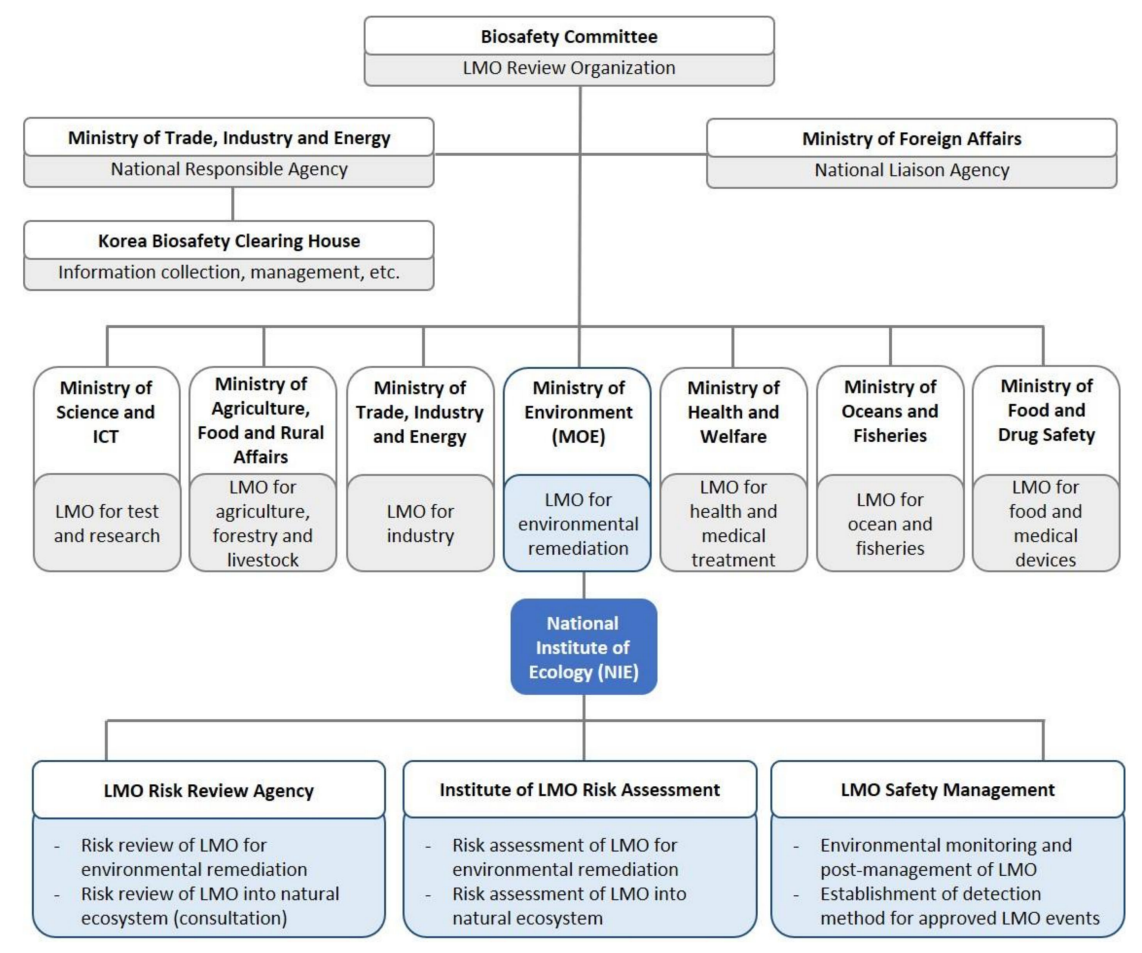

Figure 1. South Korean living modified organisms (LMOs) management system based on the LMOs Act and the roles of the Ministry of Environment and the National Institute of Ecology.

The National Institute of Ecology (NIE), a government-affiliated institute under the MOE, has been delegated affairs concerning the safety management of LMOs, led by the MOE; it was designated as an LMO risk review agency in January 2015 and as an institute of LMO risk assessment in December $2018[4,5]$. The NIE establishes standards and methods for the risk review and assessment of LMOs for environmental remediation. It further reviews, by consultation, the effects of new LMOs on the natural ecosystem. In addition, the NIE investigates the unintentional release of LMOs into natural ecosystems and follows up their spread in the populations of wild relatives. The roles of the MOE and NIE for the risk assessment of LMOs are detailed in Figure 2.

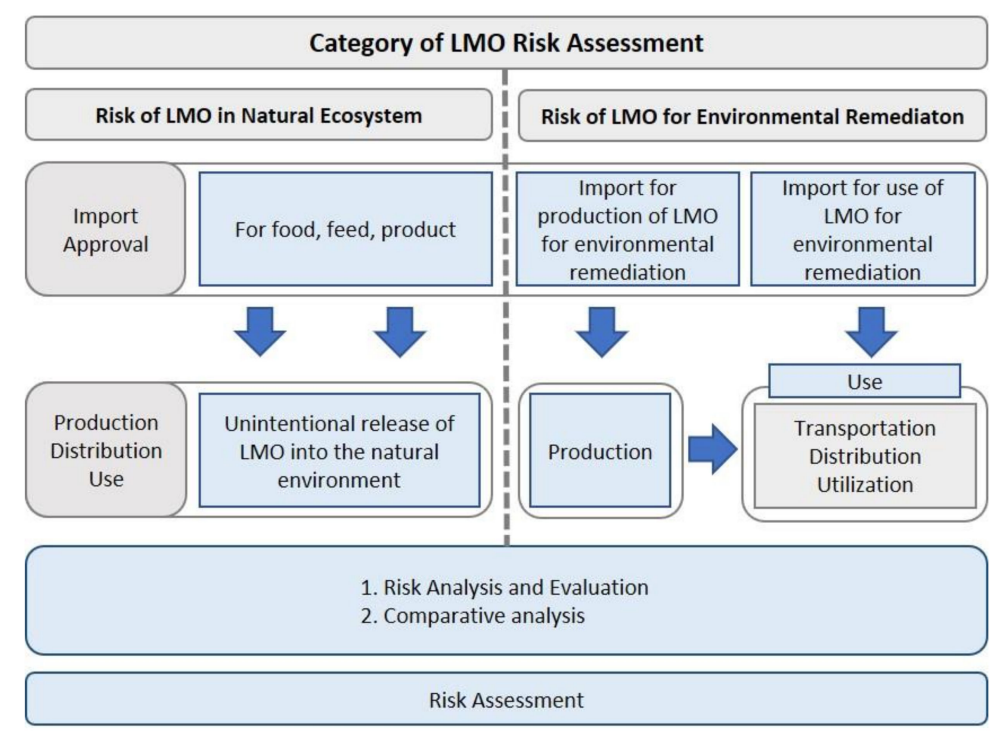

Figure 2. Risk assessment system of living modified organisms (LMOs) led by the Ministry of Environment. 
Since 2008, South Korea has been importing LMOs for use as food, feed, or processing, and the total cumulative amount of imported LMOs during the period 2008-2019 was over 110 million tons [6]. Simultaneously, there is an increasing possibility of seed spillage leading to the unintentional escape of LMOs into the natural environment during their transportation and utilization. Although the field cultivation of transgenic plants is not permitted in Korea, transgenic volunteers have been detected around feed factories, livestock barns, small vegetable gardens, and festival places, as well as in ports and along the transportation routes [7-10]. In 2017, a large amount of herbicide-tolerant oilseed rape GT73 and insect-resistant cotton MON531 was found in flower festival-hosting regions and in cultivation fields, respectively [10-12]. These volunteers caused by the unintentional or accidental release of transgenic seeds may adversely affect the variation in natural populations.

The invasion of transgenic seeds into natural ecosystems is a major environmental concern, along with transgene introgression or hybridization [13]. Competitive invaders can disturb the biodiversity in natural habitats, and therefore it is important to detect potential invasiveness early [14]. Raybould [15] suggested that seed production and dispersal are early-stage processes associated with the weediness and invasiveness of transgenic plants. Increased quantities of transgenic seeds could lead to seed dispersal over larger areas and could result in larger seed banks in the disturbed environments [16]. Furthermore, the distribution of soil seed banks across large areas promotes the persistence of volunteer populations during periods of unfavorable growth conditions [17]. However, as the seeds in a soil seed bank may lose their viability in response to high soil temperatures and moisture or unsuitable duration and depth of burial or soil type, seed viability is an important indicator in predicting the potential invasiveness of transgenic plants [18-20].

On the contrary, transgenic plants can be used to remediate disturbed environments, including long-term contaminated sites, and therefore the ecological effects of these plants should be more carefully considered. Although the commercial cultivation of transgenic plants for environmental remediation has not been approved anywhere in the world, several transgenic plants intended to reduce or remove environmental pollutants have been developed [21-24]. Moreover, several transgenic plants for phytoremediation have been approved for experimental field release in the USA and Germany [25-29]. In South Korea, field trials for the environmental release of heavy metal-tolerant transgenic poplar have been conducted in abandoned mine sites [30,31]. As the commercialization of transgenic plants for environmental remediation is imminent, it is necessary to set up a standard for the risk review and assessment of these transgenic plants in natural ecosystems and to prepare for their unintentional escape, especially in the seed state.

Here, we investigated whether the seeds of plants used for environmental remediation can persist in natural ecosystems in South Korea by comparing the viability of seeds under laboratory and field conditions (Figure 3). Sunflower (Helianthus annuus L.), a promising candidate for phytoremediation due to its heavy metal-hyperaccumulating efficiency, was considered in this study [32-34]. Sunflower is also a good material with which to examine seed viability, because it produces large amounts of seeds annually, forms persistent seed banks, and is often observed in disturbed areas [16,35]. The unintentional spillage of LMO seeds may occur during seed transportation and utilization throughout the year; therefore, we conducted our study during the spring season, when seeds are most likely to germinate. Our results could support the development of appropriate research tools to determine factors affecting the invasiveness of transgenic plants used for environmental remediation. 


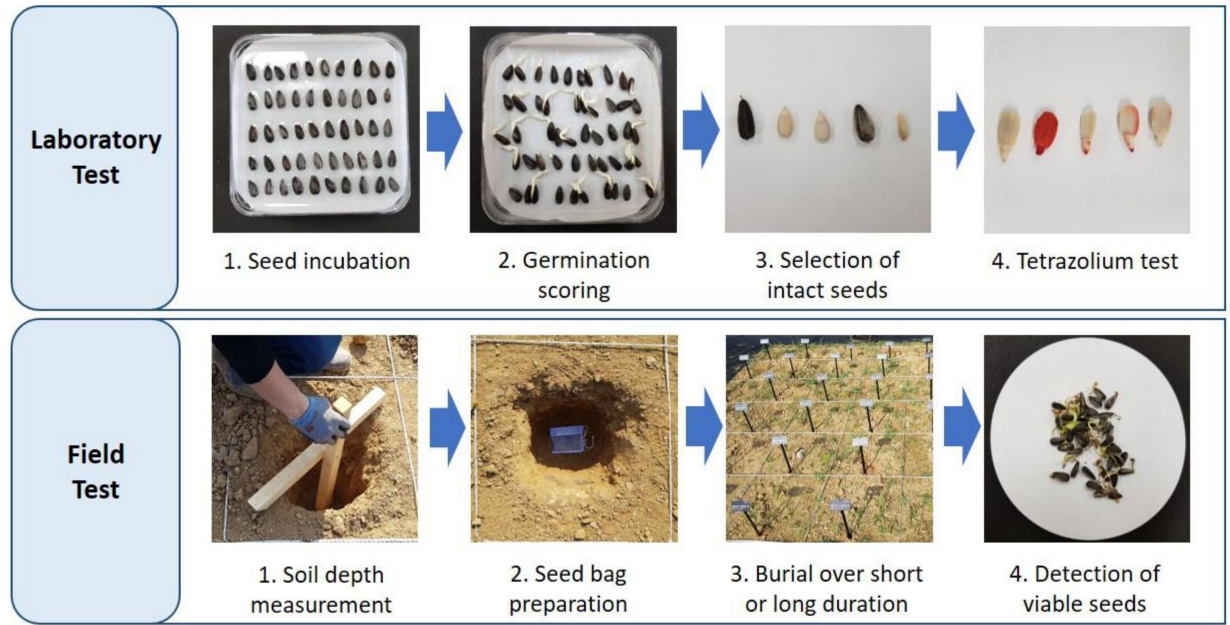

Figure 3. Method for testing the viability of seeds under laboratory and field conditions.

\section{Materials and Methods}

\subsection{Plant Materials}

Five sunflower cultivars, Jaeraejongja (height, 1.6-1.8 m; standard type), Jaeraejong (height, 1.0-1.6 m; semi-dwarf type), Jaeraejong1 (height, 0.5-1.0 m; dwarf type), Jaeraejong2 (height, $<0.5 \mathrm{~m}$; extreme dwarf type), and Jaeraejong3 (height, <0.5 m; extreme dwarf type) [36], were purchased from Danong Co. (Namyangju, Korea). The physical characteristics of their seeds, including length, width, thickness, and weight, are presented in Table 1.

Table 1. Physical characteristics of five sunflower cultivar seeds.

\begin{tabular}{cccccc}
\hline \multirow{2}{*}{ Cultivars } & \multicolumn{4}{c}{ Seeds } & \multirow{2}{*}{ Seed Category $^{\mathbf{1}}$} \\
\cline { 2 - 5 } & Length $(\mathbf{m m})$ & Width $\mathbf{( m m )}$ & Thickness $(\mathbf{m m})$ & Weight $\mathbf{( m g )}$ & \\
\hline p-value & $<0.001$ & $<0.001$ & $<0.001$ & $<0.001$ & \\
Jaeraejongja & $12.3 \pm 0.6^{\mathrm{a}}$ & $6.0 \pm 0.9^{\mathrm{a}}$ & $3.9 \pm 0.3^{\mathrm{a}}$ & $84.5 \pm 18.3^{\mathrm{a}}$ & Large \\
Jaeraejong & $9.5 \pm 0.1^{\mathrm{b}}$ & $4.4 \pm 0.6^{\mathrm{b}}$ & $2.6 \pm 0.4^{\mathrm{c}}$ & $40.8 \pm 10.9^{\mathrm{c}}$ & Medium \\
Jaeraejong1 & $7.9 \pm 0.9^{\mathrm{d}}$ & $4.3 \pm 1.0^{\mathrm{b}}$ & $3.0 \pm 0.6^{\mathrm{b}}$ & $38.1 \pm 13.0^{\mathrm{c}}$ & Small \\
Jaeraejong2 & $9.2 \pm 1.1^{\mathrm{c}}$ & $4.4 \pm 0.8^{\mathrm{b}}$ & $3.1 \pm 0.5^{\mathrm{b}}$ & $49.6 \pm 15.9^{\mathrm{b}}$ & Medium \\
Jaeraejong3 & $6.6 \pm 0.7^{\mathrm{e}}$ & $3.4 \pm 0.5^{\mathrm{c}}$ & $2.4 \pm 0.4^{\mathrm{d}}$ & $20.6 \pm 5.2^{\mathrm{d}}$ & Small \\
\hline
\end{tabular}

Note: data are means $(n=5) \pm$ standard deviations, and each replicate consisted of 20 seeds. $p$-values are based on one-way ANOVA, and values in a column followed by same letters are not significantly different at the 0.05 level using Duncan's test. ${ }^{1}$ Seed samples were classified into three categories according to the method of Gupta and Das [37]: large (length $>10 \mathrm{~mm}$; Jaeraejongja), medium $(8<$ length $<10 \mathrm{~mm}$; Jaeraejong, Jaeraejong2), and small (length $<8 \mathrm{~mm}$; Jaeraejong1, Jaeraejong3).

\subsection{Seed Germination Test}

According to the International Rules for Seed Testing [38], fifty seeds from each cultivar were placed into a $125 \times 125 \mathrm{~mm}$ Petri dish (SPL Life Sciences Co., Ltd., Pocheon, Korea) on Whatman filter paper moistened with $20 \mathrm{~mL}$ of distilled water and randomly assigned to eight replications (Figure 3). The seeds were then incubated in a growth chamber (Sanyo MLR-352H; Panasonic Healthcare Co., Ltd., Oizumi, Japan) under two conditions: (i) a constant temperature of $25{ }^{\circ} \mathrm{C}$ with darkness and (ii) alternating temperatures of $30 / 20{ }^{\circ} \mathrm{C}$ under a $16 \mathrm{~h}$ light/8 h dark cycle. Germinated seeds were counted and removed daily for up to $7 \mathrm{~d}$. Seeds were considered to have germinated when their radical length reached more than $2 \mathrm{~mm}$. Germination was calculated as the percentage of seeds that germinated out of the total number of seeds. 
After $7 \mathrm{~d}$ of incubation, a tetrazolium (TZ) test was conducted on intact non-germinated seeds to check their viability [37]. The number of viable and non-viable seeds was counted, and the proportion of germinated, dormant, and dead seeds for each cultivar was scored by combining the results of the incubation test and the $\mathrm{TZ}$ test.

\subsection{Seed Burial Experiment}

Field experiments were conducted at a confined field located at the NIE, Seocheon-gun, South Korea $\left(36^{\circ} 01^{\prime} 43.0^{\prime \prime} \mathrm{N}, 126^{\circ} 43^{\prime} 23.7^{\prime \prime} \mathrm{E}\right.$; elevation: $\left.20 \mathrm{~m}\right)$, based on the modified method of Alexander and Schrag. [35] (Figure 3). Two sunflower cultivars, Jaeraejongja and Jaeraejong3, were selected for this study. Three fully randomized blocks were set up, and 96 plots (size: $50 \mathrm{~cm} \times 50 \mathrm{~cm}$ ) were established within each block in April 2020. Fifty seeds mixed into $50 \mathrm{~cm}^{3}$ of sterilized sand were enclosed in a seed bag $(12 \mathrm{~cm} \times 16 \mathrm{~cm})$ made of nylon mesh (size: $0.3 \mathrm{~mm})$ and secured using a cord. These bags were buried in the center of a plot at depths of $0,2,5,10,15$, and $30 \mathrm{~cm}$. During the experiment period, the plots were left undisturbed.

Seed bags were retrieved 1, 2, 3, 4, 6, 8, and 16 weeks after burial. The mixture of seeds and sand was placed on a 2-mm sieve to separate the sand and seeds, and the filtered seeds were washed with distilled water. The number of germinated and dead seeds was counted, and germination was calculated as the percentage of germinated seeds out of the total number of seeds.

Intact ungerminated seeds were then incubated in a growth chamber (Sanyo MLR-352H) at a constant temperature of $25^{\circ} \mathrm{C}$ under darkness for $7 \mathrm{~d}$, as described above. After $7 \mathrm{~d}$, the seeds that germinated were counted, and a TZ test was performed for the remaining hard seeds. For seed burial experiment, the proportion of germinated seeds were scored by dividing the initial number of seeds germinated after burial and that germinated after the 7-day incubation test.

\subsection{Soil Physico-Chemical Properties}

The daily soil temperature and moisture levels in the field were recorded at 10,20,30, 40, and $50 \mathrm{~cm}$ soil depths over 16 weeks with HOBO Temp data loggers (U30-NRC-10-S100; Onset Computer Co., Pocasset, MA, USA). The daily air temperature and precipitation were taken from the daily weather report for the Gunsan Meteorological Station ( $36^{\circ} 00^{\prime} 19.1^{\prime \prime} \mathrm{N}, 126^{\circ} 45^{\prime} 40.9^{\prime \prime} \mathrm{E} ; 23.2 \mathrm{~m}$ above sea level) [39]. Climate data for the period between 1 January 2010 and 31 December 2019 in South Korea were obtained from the Korea Meteorological Administration [40].

The soil chemical and physical characteristics were analyzed according to the National Institute of Agricultural Science and Technology (NIAST) soil and plant analysis methods [41]. Samples were collected from 5, 15, and $30 \mathrm{~cm}$ soil depths in the experimental field. The soil moisture content was determined based on the difference in weight between the initial samples and after drying the samples at $105^{\circ} \mathrm{C}$ until a constant weight was reached. The soil pH and electrical conductivity (EC) were determined using a $\mathrm{pH}$ meter (Starter 3100, Ohaus, NJ, USA) and EC meter (Orion Star A329, Thermo Scientific, Waltham, MA, USA), respectively. The organic matter content was estimated based on the weight lost after the samples were kept in a crucible at $450{ }^{\circ} \mathrm{C}$ for $45 \mathrm{~min}$. The total nitrogen content was determined using the Kjeldahl method, and the available phosphorus content was determined via the Lancaster method using a spectrophotometer (UV-1800; Simadzu, Japan). The cation exchange capacity (CEC) was calculated after saturating the samples with $1 \mathrm{~N} \mathrm{NH}_{4} \mathrm{OAc}$ ( $\mathrm{pH}$ 7.0), and exchangeable cations $\left(\mathrm{Ca}^{2+}, \mathrm{K}^{+}, \mathrm{Mg}^{2+}\right.$, and $\mathrm{Na}^{+}$) were measured via inductively coupled plasma optical-emission spectroscopy (5100; Agilent, Santa Clara, CA, USA). The soil texture was determined using the hydrometer method.

\subsection{Statistical Analysis}

All the analyses were performed using STATISTICA (version 8.0; StatSoft Inc., Tulsa, OK, USA) or SAS Studio (version 3.8; SAS Institute Inc., Cary, NC, USA). Data were analyzed via analysis of variance (ANOVA) and tested at a 5\% significance level. If the ANOVA showed significant differences between 
means, Duncan's multiple comparison test was used to determine their differences. To analyze the effects of sunflower cultivar, duration of burial, depth of burial, and their interactions on germination rates, ANOVA was performed using a general linear model (GLM) module. The regression analysis function of Sigmaplot (version 12.5; Systat Software Inc., San Jose, CA, USA) was used to obtain best-fit curves.

\section{Results}

\subsection{Seed Germination at Different Controlled Temperatures}

The sunflower seed germination rates differed significantly according to the cultivar and temperature (Figure 4). Overall, the cumulative germination was high in Jaeraejong2 and Jaeraejongja, regardless of the temperature conditions. Days to reach almost complete germination varied by cultivars under both temperature conditions. Under constant temperatures, the total germination during the test period was $84.0 \%, 78.5 \%$, and $74.0 \%$ for Jaeraejong2, Jaeraejong3, and Jaeraejongja, respectively (Figure $4 \mathrm{a}, \mathrm{c}$ ). However, the total germination for Jaeraejong and Jaeraejong1 was $26.8 \%$ and $29.0 \%$, respectively, under constant temperatures. Under alternating temperatures, the total germination for Jaeraejong2 and Jaeraejongja was $85.8 \%$ and $80.3 \%$, respectively (Figure $4 \mathrm{~b}, \mathrm{~d}$ ). However, that of Jaeraejong3, Jaeraejong1, and Jaeraejong was 50.8\%, 36.5\%, and 22.3\%, respectively. Differences in germination rates under constant and alternating temperatures were found for Jaeraejong3 $(p<0.05)$. The overall germination rate of Jaeraejong 3 seeds was $35.4 \%$ lower under alternating temperatures than under constant temperatures.

The seed viability determined by the TZ test also varied among the sunflower cultivars and temperature conditions (Figure 4e,f). Under a constant temperature, the highest proportion of dormant seeds was observed for the Jaeraejongja cultivar, while under alternating temperatures, Jaeraejong3 seeds demonstrated the highest rate of dormancy. The proportion of dormant Jaeraejongja and Jaeraejong 3 seeds was $16.5 \%$ and $11.5 \%$, respectively, under a constant temperature, whereas that for Jaeraejong 3 and Jaeraejong 1 it was $18.0 \%$ and $12.8 \%$, respectively, under alternating temperatures. Differences in the proportion of dormant seeds under constant and alternating temperatures were found for Jaeraejong2 and Jaeraejong3 $(p<0.05)$. The proportion of dormant Jaeraejong2 seeds was reduced by $62.9 \%$ under alternating temperatures compared to that under constant temperatures, whereas for Jaeraejong 3 the proportion of dormant seeds increased by $56.5 \%$ under alternating temperatures.

\subsection{Viability of Seeds Buried at Various Soil Depths}

In our laboratory experiment, the germination rate of Jaeraejongja did not differ under constant and alternating temperatures, whereas that of Jaeraejong3 differed significantly under the two temperature regimes. In addition, the seed size and weight and plant height clearly differed between Jaeraejongja and Jaeraejong3. Therefore, based on these differences in the seed physical properties, plant phenotypic traits, and germination characters, we selected the Jaeraejongja and Jaeraejong 3 cultivars to study the viability of seeds buried in the soil. In South Korea, the mean annual temperature and precipitation for the period of 2010-2019 were $13.0^{\circ} \mathrm{C}$ and $1264.4 \mathrm{~mm}$, respectively (Figure 5a,b) [40]. During the test period, the mean daily air temperature and precipitation were $11.2-26.1^{\circ} \mathrm{C}$ and $0-61.8 \mathrm{~mm}$, respectively (Figure $5 \mathrm{c}, \mathrm{d}$ ) [39]. In addition, the mean daily soil temperature was $14.7-27.7^{\circ} \mathrm{C}$, and daily soil moisture was $14.8-45.4 \%$ at a depth of $10 \mathrm{~cm}$ (Figure $5 \mathrm{e}, \mathrm{f})$. Soil temperature decreased as the soil depth increased, and the difference in temperature between soil depths of $10 \mathrm{~cm}$ and $30 \mathrm{~cm}$ was approximately $2.9^{\circ} \mathrm{C}$. Soil moisture increased on days with precipitation, and elevated soil moisture was maintained longer as the soil depth increased. Throughout the test period, the differences in daily soil temperature and moisture were statistically significant with varying soil depths, though the soil moisture content at nine and twelve weeks after burial did not differ significantly. The soil physio-chemical properties did not statistically differ between soil depths of 5, 15, and $30 \mathrm{~cm}$ (Table 2). 
(a)

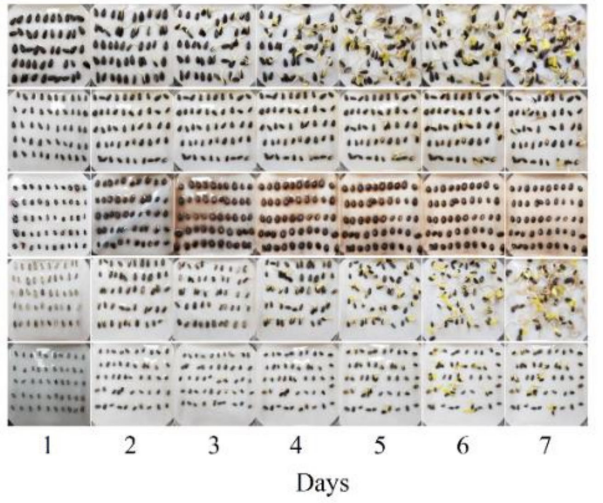

(c)

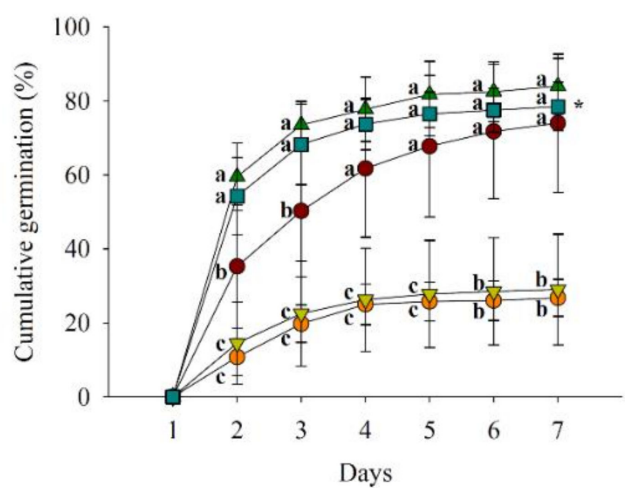

(e)

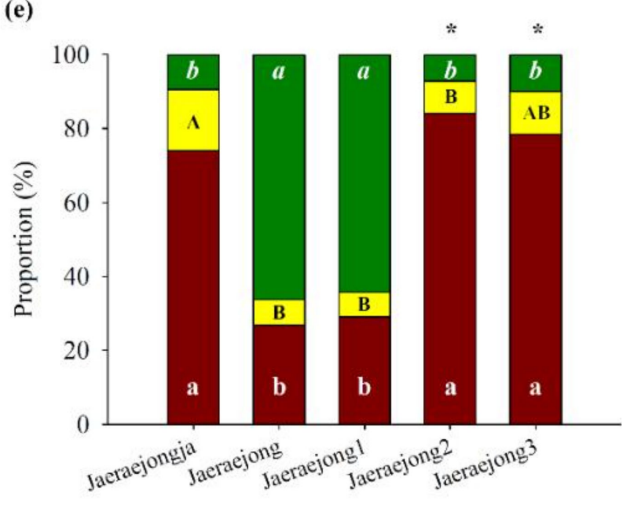

(b)

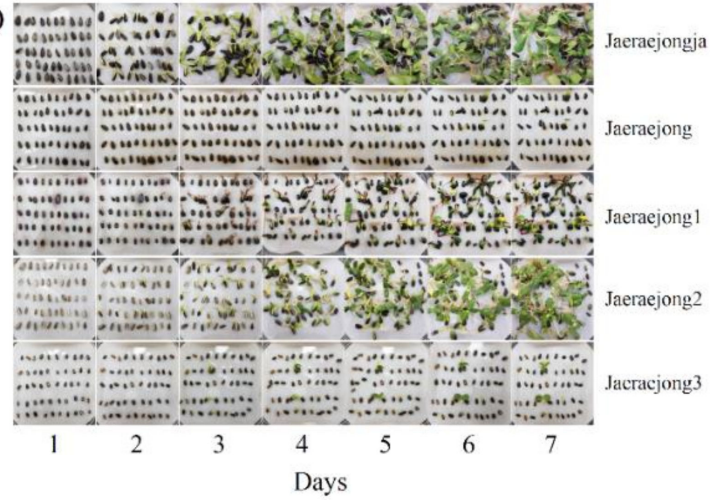

(d)

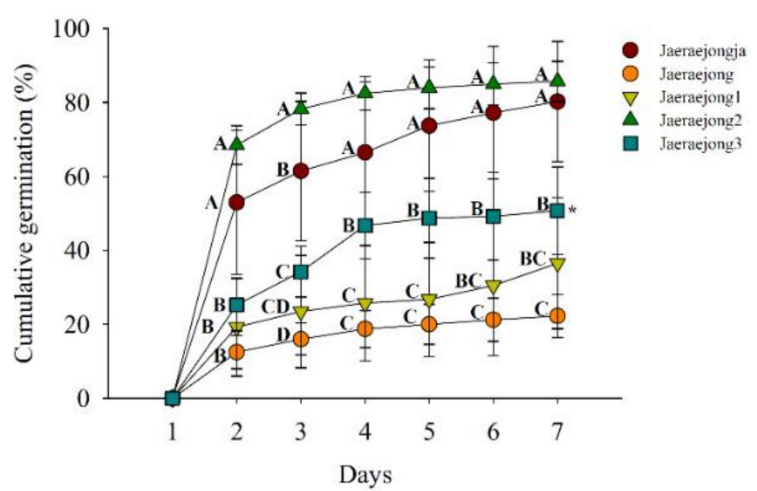

(f)

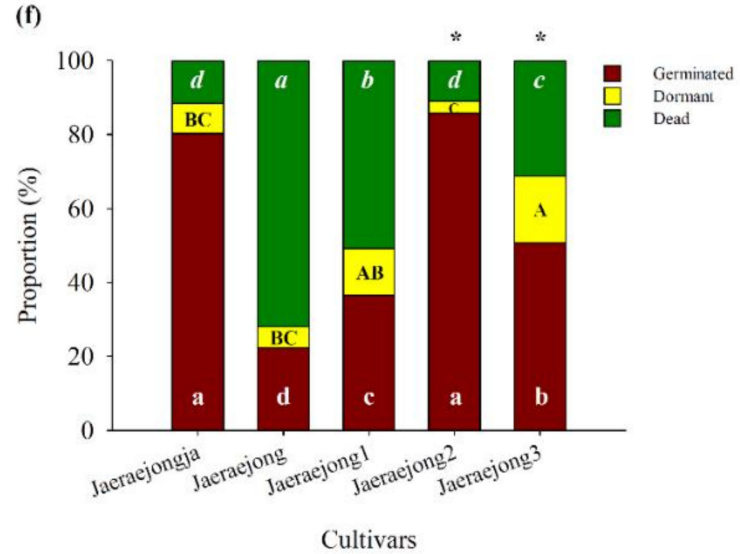

Figure 4. Changes in the germination of seeds of five sunflower cultivars under $(\mathbf{a}, \mathbf{c})$ a constant temperature of $25^{\circ} \mathrm{C}$ and $(\mathbf{b}, \mathbf{d})$ alternating temperatures of $30 / 20^{\circ} \mathrm{C}$ over $7 \mathrm{~d}$. The proportion of germinated, dormant, and dead seeds of the five sunflower cultivars under (e) a constant temperature of $25^{\circ} \mathrm{C}$ and (f) alternating temperatures of $30 / 20^{\circ} \mathrm{C}$. Data are presented as means $(n=8) \pm$ standard deviations. Different letters indicate significant differences among cultivars at the $p<0.05$ level by one-way ANOVA. Asterisks indicate significant differences at the $p<0.05$ level between outcomes under constant and alternating temperature. 
(a)

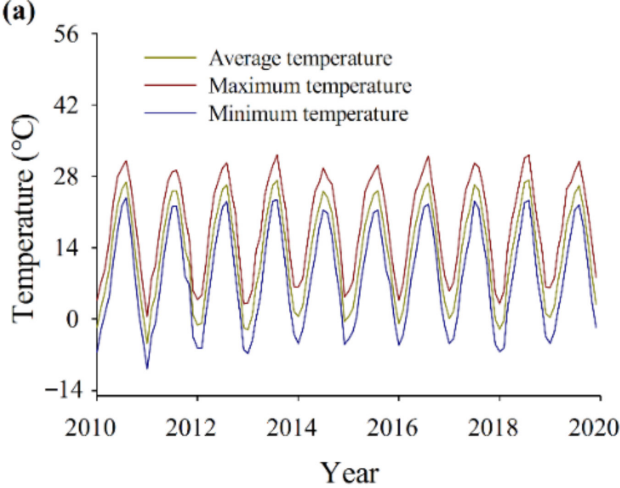

(c)

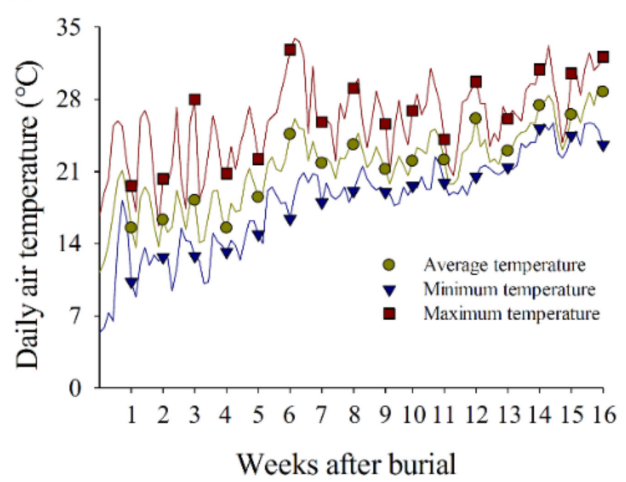

(e)

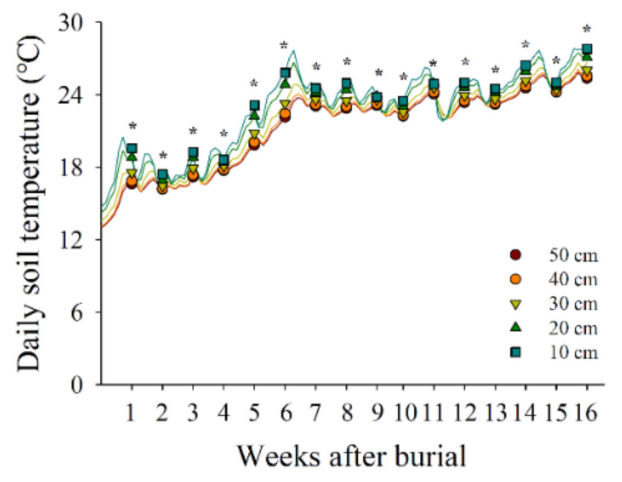

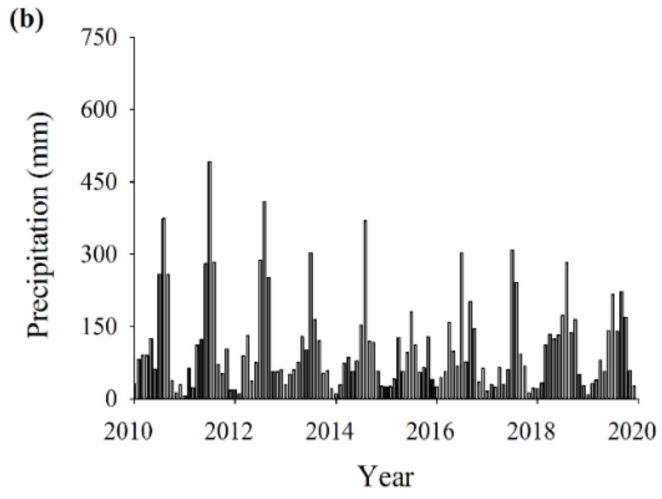

(d)

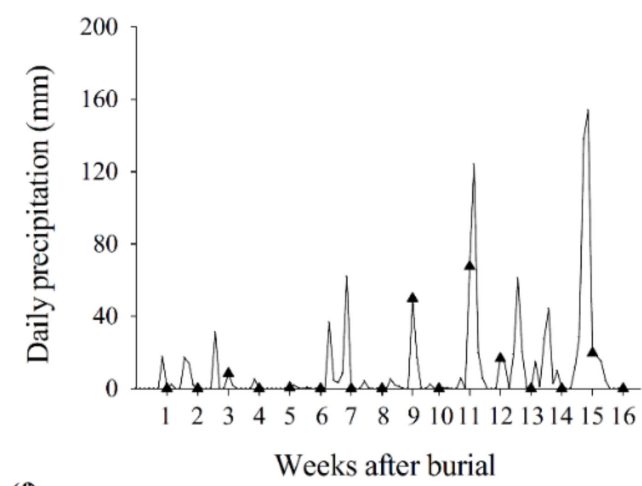

(f)

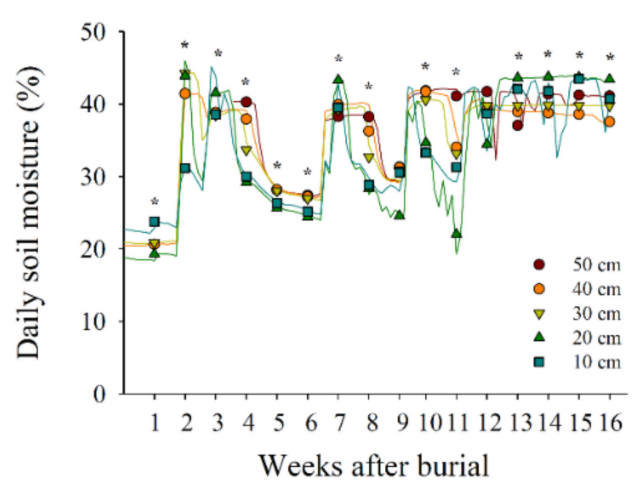

Figure 5. (a) Long-term temperature and (b) precipitation data between 1 January 2010 and 31 December 2019 in South Korea [40]. Variations in the (c) daily air temperature and (d) precipitation [39]; (e) daily mean soil temperature and (f) moisture in the field trial site during the burial period from April to August 2020. The soil temperature and moisture were measured at the depths of 10, 20,30, 40, and $50 \mathrm{~cm}$. Asterisks indicate significant differences among soil depths at the $p<0.05$ level by one-way ANOVA. 
Table 2. Soil physicochemical properties at different soil depths.

\begin{tabular}{|c|c|c|c|c|}
\hline \multirow{2}{*}{ Soil Characteristics } & \multirow{2}{*}{$p$-Value } & \multicolumn{3}{|c|}{ Soil Depth (cm) } \\
\hline & & 5 & 15 & 30 \\
\hline Moisture (\%) & 0.285 & $12.2 \pm 0.3$ & $13.3 \pm 2.9$ & $10.8 \pm 0.4$ \\
\hline $\mathrm{pH}$ & 0.086 & $6.2 \pm 0.1$ & $6.3 \pm 0.1$ & $6.4 \pm 0.1$ \\
\hline $\mathrm{EC}\left(\mathrm{ds} \mathrm{m^{-1 } )}\right.$ & 0.706 & $0.2 \pm 0.1$ & $0.2 \pm 0.1$ & $0.2 \pm 0.1$ \\
\hline Organic matter (\%) & 0.399 & $4.4 \pm 0.7$ & $4.0 \pm 0.2$ & $4.8 \pm 0.8$ \\
\hline Total N (mg kg $\left.{ }^{-1}\right)$ & 0.330 & $580.9 \pm 204.6$ & $424.9 \pm 185.3$ & $363.4 \pm 91.0$ \\
\hline $\mathrm{P}_{2} \mathrm{O}_{5}\left(\mathrm{mg} \mathrm{kg}^{-1}\right)$ & 0.677 & $19.0 \pm 7.6$ & $23.0 \pm 7.7$ & $23.6 \pm 4.0$ \\
\hline $\mathrm{CEC}\left(\mathrm{cmol}^{+} \mathrm{kg}^{-1}\right)$ & 0.479 & $13.7 \pm 1.6$ & $12.4 \pm 0.8$ & $12.7 \pm 1.3$ \\
\hline Exchangeable Ca $\left(\mathrm{cmol}^{+} \mathrm{kg}^{-1}\right)$ & 0.748 & $6.7 \pm 1.0$ & $6.4 \pm 0.4$ & $6.3 \pm 0.4$ \\
\hline Exchangeable $\mathrm{K}\left(\mathrm{cmol}^{+} \mathrm{kg}^{-1}\right)$ & 0.313 & $0.4 \pm 0.3$ & $0.2 \pm 0.0$ & $0.2 \pm 0.0$ \\
\hline Exchangeable $\mathrm{Mg}\left(\mathrm{cmol}^{+} \mathrm{kg}^{-1}\right)$ & 0.978 & $4.5 \pm 0.8$ & $4.4 \pm 0.4$ & $4.4 \pm 0.3$ \\
\hline Exchangeable $\mathrm{Na}\left(\mathrm{cmol}^{+} \mathrm{kg}^{-1}\right)$ & 0.784 & $0.3 \pm 0.0$ & $0.3 \pm 0.0$ & $0.3 \pm 0.0$ \\
\hline Sand $(\%)$ & 0.501 & $56.3 \pm 3.1$ & $57.8 \pm 2.1$ & $55.5 \pm 1.3$ \\
\hline Silt (\%) & 0.604 & $26.3 \pm 2.0$ & $24.6 \pm 3.0$ & $25.9 \pm 0.8$ \\
\hline Clay (\%) & 0.397 & $17.3 \pm 1.2$ & $17.7 \pm 1.5$ & $18.7 \pm 0.6$ \\
\hline Soil texture & & Sandy Loam & Sandy Loam & Sandy Loam \\
\hline
\end{tabular}

Note: data are means $(n=3) \pm$ standard deviations. $p$-values are based on one-way ANOVA tests. EC: electrical conductivity; CEC: cation exchange capacity.

The germination and viability of seeds buried in soil were significantly affected by burial depth $(p<0.001)$, duration $(p<0.001)$, and cultivar $(p<0.001)$ (Table 3$)$. In addition, significant interactions were found between duration $\times$ cultivar $(p<0.001)$, duration $\times$ depth $(p<0.001)$, cultivar $\times$ depth $(p<0.001)$, and duration $\times$ cultivar $\times$ depth $(p<0.001)$.

Table 3. General linear model (GLM) results for seed germination and viability obtained for two sunflower cultivars at six burial depths and seven burial durations.

\begin{tabular}{cccccc}
\hline Source & SS $^{\mathbf{1}}$ & DF $^{\mathbf{2}}$ & MS $^{\mathbf{3}}$ & $\boldsymbol{F}^{\mathbf{4}}$ & $\boldsymbol{p}^{\mathbf{5}}$ \\
\hline Duration of burial & $103,582.9$ & 6 & 17263.8 & 3061.6 & $<0.001$ \\
Cultivar & 1676.6 & 1 & 1676.6 & 297.3 & $<0.001$ \\
Depth of burial & 3993.4 & 5 & 798.7 & 141.6 & $<0.001$ \\
Duration $\times$ cultivar & 4293.7 & 6 & 715.6 & 126.9 & $<0.001$ \\
Duration $\times$ depth & $11,482.1$ & 30 & 382.7 & 67.8 & $<0.001$ \\
Cultivar $\times$ depth & 446.5 & 5 & 89.3 & 15.8 & $<0.001$ \\
Duration $\times$ cultivar $\times$ depth & 5928.5 & 30 & 197.6 & 35.0 & $<0.001$ \\
\hline Error & 947.3 & 168 & 5.6 & - & - \\
\hline
\end{tabular}

Note: ${ }^{1}$ SS, Sum of Squares; ${ }^{2}$ DF, Degrees of Freedom; ${ }^{3}$ MS, Mean Square; ${ }^{4}$ F, F-statistic; ${ }^{5} p, p$-value.

Jaeraejongja seeds decayed within eight weeks and Jaeraejong3 seeds decayed within four weeks at burial depths of 2-30 cm (Figure 6). However, some Jaeraejongja and Jaeraejong3 seeds buried at $0 \mathrm{~cm}$ germinated even after eight weeks. Except at the 15 and $30 \mathrm{~cm}$ burial depths, Jaeraejongja seeds maintained a relatively high viability until four weeks after burial, and Jaeraejong3 seeds showed a relatively high viability for three weeks. Differences in germination rates between Jaeraejongja and Jaeraejong3 were found after three and four weeks of burial. 
(a)

\begin{tabular}{|c|c|c|c|c|c|c|}
\hline $\cos c 5$ & 000026 & $\ldots<2<2$ & $\ldots . . \times 38$ & ........ सैंड & ...... है & 905 \\
\hline 000006 & 20, tas &.$\zeta \xi$ & $\{\xi\}$ & ......... 2es & $\ldots$ & 0.00 \\
\hline popetit & $0,\{\}\}$ & $\ldots\{\xi\}$ & $\sum \xi \xi$ & ... … . , & n... & 002000 \\
\hline 000232 & 36 & . उद्ध & \{दू & $\cdots$ & 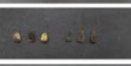 & 690000 \\
\hline 20068 & 20056 & .... $5 \xi$ & 532 & 0000 & $\cdots e$ & $\cdots$ \\
\hline Dorter & 0008 & & $\ldots \ldots$ & 00060 & $\ldots 000$ & 00000 \\
\hline
\end{tabular}

(b)

\begin{tabular}{|c|c|c|c|c|c|c|}
\hline 10.11 & $3 .+104$ & 9)3 & xyk & ... मैर्ष & ... दर & $\cdots, 0.0$ \\
\hline nonis & .126 & .25 & 0 & ... $\cdots$ & 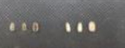 & 000000 \\
\hline$\ldots, 607$ & 2J) &. .337 & & $\begin{array}{ll}\ldots & \ldots\end{array}$ & ... & w \\
\hline Nas ine & sir & |3 & $\cdots$ & ... & & $=0$ \\
\hline wh or & $\int C_{6}$ & & . . . & ... & . & sones \\
\hline a... nove & 625 & sise two & ... & & $\cdots$ & $0,0 . .1$ \\
\hline
\end{tabular}

(c)

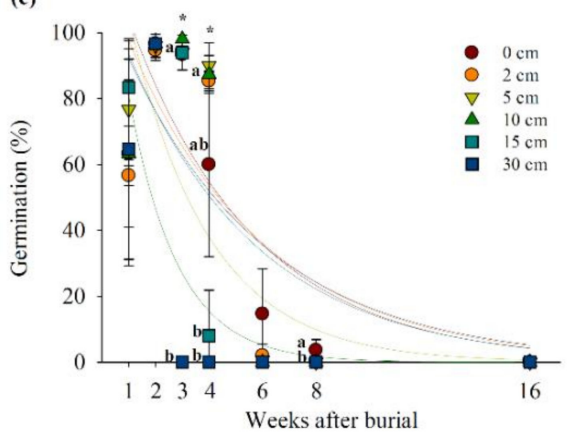

(d)

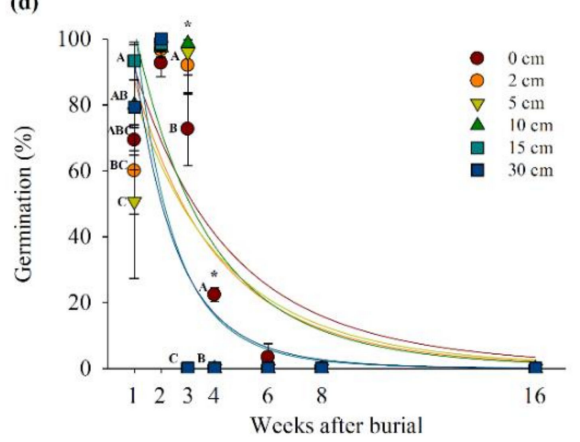

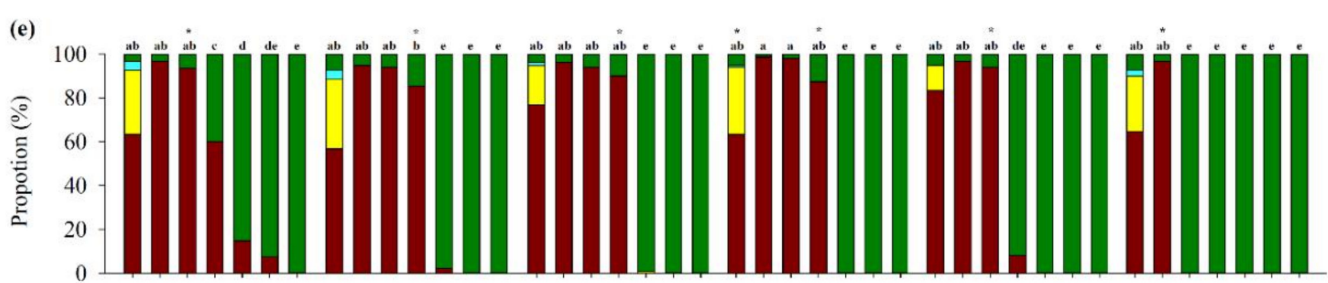

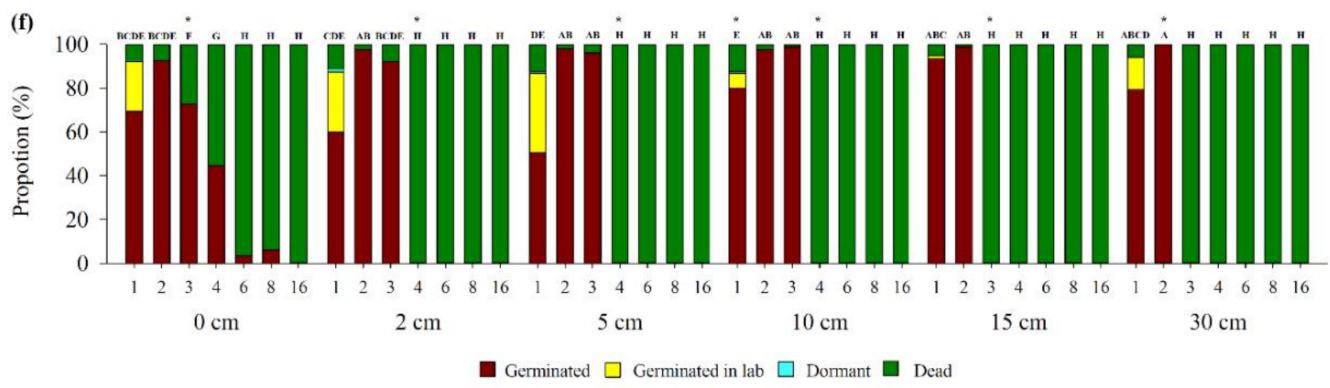

Figure 6. Changes in the germination of seeds of (a) Jaeraejongja and (b) Jaeraejong 3 and the exponential decay curves of (c) Jaeraejongja and (d) Jaeraejong3 for seeds that were viable for 1, 2, 3, 4, 6, 8, and 16 weeks after burial at soil depths of $0,2,5,10,15$, and $30 \mathrm{~cm}$. The proportion of germinated, dormant, and dead (e) Jaeraejongja and (f) Jaeraejong3 seeds buried for 1, 2, 3, 4, 6, 8, and 16 weeks at soil depths of $0,2,5,10,15$, and $30 \mathrm{~cm}$. Data are presented as means $(n=3) \pm$ standard deviations. Different letters indicate significant differences at the $p<0.05$ level among $(\mathbf{c}, \mathbf{d})$ burial depths by one-way ANOVA and $(\mathbf{e}, \mathbf{f})$ the interaction of duration $\times$ depth by two-way ANOVA. Asterisks indicate significant differences at the $p<0.05$ level between the Jaeraejongja and Jaeraejong 3 cultivars. 
For Jaeraejongja seeds, no significant differences between viability at different burial depths were observed at one and two weeks after burial (Figure $6 a, c)$. Germination after one week of burial varied from $56.7 \%$ to $83.3 \%$ depending on burial depth, but after two weeks of burial it exceeded $94.7 \%$ in all burial depths. After three weeks of burial, clear differences were observed based on burial depth. Specifically, no seeds germinated at depths of $30 \mathrm{~cm}$, while $93.3-98.0 \%$ of those buried at other depths germinated after three weeks of burial. After four weeks of burial, the seed germination rapidly declined by $8.0 \%$ at a depth of $15 \mathrm{~cm}$, while $60.0-90.0 \%$ germination rates were recorded at depths of $0-10 \mathrm{~cm}$. Germinated seeds were not found at 15 and $10 \mathrm{~cm}$ depths after six weeks of burial. After eight weeks of burial, the germination rate was only $7.3 \%$ at a depth of $0 \mathrm{~cm}$, and no seeds germinated at the other depths.

For the Jaeraejong3 seeds, the highest total germination rate was found at a depth of $15 \mathrm{~cm}$ (93.3\%), while the lowest was observed at a depth of $5 \mathrm{~cm}(50.7 \%)$ after one week of burial (Figure $6 \mathrm{~b}, \mathrm{~d}$ ). After two weeks of burial, germination was more than $92.7 \%$ at all burial depths, similar to the results for Jaeraejongja. After three or more weeks of burial, germinated seeds were not observed at depths of $15 \mathrm{~cm}$ and $30 \mathrm{~cm}$, while germination rates of 72.7-98.7\% were recorded at depths of $0-10 \mathrm{~cm}$. The germination rate was $44.7 \%$ at a depth of $0 \mathrm{~cm}$, but no seeds germinated at $2-30 \mathrm{~cm}$ soil depths after four weeks of burial. The germination at a depth of $0 \mathrm{~cm}$ was significantly reduced to $3.3 \%$ after six weeks of burial.

Of the retrieved seeds, intact ungerminated seeds were found for both the Jaeraejongja and Jaeraejong3 cultivars up to two weeks after burial (Figure 6e,f). However, such seeds were not detected at any soil depth after three weeks of burial. The proportion of dormant seeds were $0.0-4.0 \%$, and they were only observed within one week of burial. The highest proportion of germinated and dormant seeds was found at a depth of $10 \mathrm{~cm}$ after two and three weeks of burial for Jaeraejongja, while these proportions were highest after two weeks of burial at a $30 \mathrm{~cm}$ depth for Jaeraejong3. Differences in the proportion of germinated and dormant seeds between Jaeraejongja and Jaeraejong3 were found at depths of $0 \mathrm{~cm}$ and $15 \mathrm{~cm}$ after three weeks of burial, at depths of $2 \mathrm{~cm}$ and $5 \mathrm{~cm}$ after four weeks of burial, at depths of $10 \mathrm{~cm}$ after one and four weeks of burial, and at depths of $30 \mathrm{~cm}$ after two weeks of burial.

\section{Discussion}

Seed germination and dormancy dynamics are involved in population persistence, intra- and interspecific competition, and plant fitness [42]. These factors are largely affected by temperature and are species-dependent [43]. Non-dormant sunflower seeds are reported to germinate well under a broad range of temperatures $\left(5-40^{\circ} \mathrm{C}\right)$, with the optimum temperature being $25^{\circ} \mathrm{C}$ [44]. We found that the germination rates of five sunflower cultivars ranged from $26.8 \%$ to $84.0 \%$ at constant temperatures of $25^{\circ} \mathrm{C}$ and from $22.3 \%$ to $85.8 \%$ at alternating temperatures of $30 / 20^{\circ} \mathrm{C}$ in the laboratory experiment. In addition, the proportion of dormant seeds differed according to cultivar under both temperature conditions. In particular, the overall germination rate and the proportion of dormant Jaeraejong 3 seeds were $35.4 \%$ lower and $56.5 \%$ greater, respectively, under alternating temperatures than constant temperatures, implying that seed viability could be strongly affected by temperature conditions. For weeds, seed size has been reported to contribute to differences in seed germination and persistence in response to variety of environmental factors [45]. Larger seeds were more likely to produce seedlings in shaded conditions, and smaller seeds were more sensitive to various environmental conditions [46,47]. Therefore, the increased proportion of dormant seeds and decreased proportion of germinated seeds under alternating temperature conditions for the Jaeraejong 3 cultivar, which featured the smallest seeds used in the present study, may be attributable to seed size. Further, Khalifa et al. [48] noted that sunflower hybrids could successfully adapt to a wide range of climates, because genetic variations were associated with different germination temperatures. We also found that sunflower seed germination and dormancy are highly cultivar-dependent, suggesting that some sunflowers have 
the potential to survive in diverse habitats and environmental conditions and could be appropriate for use in remediation projects.

Soil seed banks play an important role in stabilizing and ensuring species survival; they also have the potential to favor competitive invaders within the population dynamics of many ecosystems [49]. However, seed banks are only functional if the seeds are deposited in a completely viable state and are ready to germinate in a timely manner [50]. Traba et al. [51] stated that studies on the relationship between burial depth and seed emergence offer important insight into the actual functionality of a soil bank. In many plant species, the seed germination and seedling emergence decrease when the burial depth increases $[52,53]$. In contrast, canola seeds buried at a deeper soil depth could persist longer than those buried at shallow depths in fields $[54,55]$.

In this study, we examined the viability of seeds from two sunflower cultivars buried at various soil depths $(0,2,5,10,15$, and $30 \mathrm{~cm})$ with different degrees of temperature and moisture in a field. The results indicated that the germination among Jaeraejongja and Jaeraejong3 seeds buried at depths of 2-10 cm significantly declined after six and four weeks of burial, respectively, whereas the germination among seeds buried at a depth of $15 \mathrm{~cm}$ was reduced after four and three weeks of burial, respectively. At a depth of $30 \mathrm{~cm}$, the germination of both cultivars decreased after two weeks of burial. Benvenuti and Macchia [56] suggested that reduced seed germination under excessive soil depth may result from secondary dormancy, an ecological adaptation mechanism that may serve to prevent germination under unsuitable conditions for seed survival and persistence. The absence of oxygen or light, fluctuations in soil temperature and moisture, and the presence of volatile or allelopathic inhibitors are known to regulate the induction of secondary dormancy in buried seeds [57,58]. However, in the present study, dormant seeds were only detected in $0-4 \%$ of seeds up to one week after burial, after which all the ungerminated seeds decayed.

Chantre et al. [59] demonstrated that seed decay increases as burial depth and period increase, and decay was further elevated by complementary water supply. Seed decay is highly affected by the activity of soil microorganisms influenced by the soil environment, including the soil temperature, moisture, and physicochemical properties [60,61]. Several studies have shown that the impact of fungicidal treatments on the survival of buried seeds is more pronounced in relatively wetter conditions [62,63]. In this study, the sunflower seed decay was markedly elevated as the burial depth and period increased. In particular, soil moisture significantly increased at two weeks after burial in conjunction with an increased decay rate of the seeds buried at a depth of $30 \mathrm{~cm}$. Even at other soil depths, most of the buried seeds decayed within eight weeks. These results indicate that sunflower seeds buried in spring could lose their viability over a short period without the induction of secondary dormancy, suggesting that these seeds might not be successfully established in the ecosystem.

On the other hand, the appearance of seedlings from buried seeds can positively correlate with larger seed sizes [64]. Although seed germination decreases with increased burial depth, the germination rate of large-sized seeds is higher than that of small seeds [65]. Furthermore, seedling survival at different burial depths has been noted to be greatly enhanced as the seed weight increases [66]. Several studies have revealed that the differences in germination and seedling emergence are due to seed size, derived from differences in energy reserves [47,67]. In our results, the seed decay at burial depths of 2-15 cm was more rapid for the Jaeraejong3 seeds than for the Jaeraejongja in an inverse proportion to the seed size and mass, reflecting a close relationship between seed viability and seed size.

\section{Conclusions}

Based on the laboratory and field results, we concluded that the germination of sunflower seeds vary strongly with the cultivars and environmental conditions. The unintentional release of transgenic seeds during their transportation and utilization could result in the formation of soil seed banks in natural environments and the subsequent proliferation of volunteer plants. In this study, we compared the germination of seeds of five sunflower cultivars at different temperatures. Furthermore, the viability of seeds buried at various soil depths (ranging from 0 to $30 \mathrm{~cm}$ ) in the spring sowing season was 
examined under undisturbed field conditions over sixteen weeks. The seed germination substantially varied with the cultivar and temperature. Field trials showed that most sunflower seeds lost their viability within eight weeks rather than entering secondary dormancy, although affected by the burial depth. In addition, smaller seeds buried at a depth of $2-15 \mathrm{~cm}$ were found to decay faster than larger seeds. Further studies, including those on the overwintering viability of seeds buried during the autumn harvest season and the effects of different soils, locations, and climate conditions, will provide valuable insights into the potential invasiveness of sunflower seeds in a range of environments. Our results suggest that each transgenic plant requires individual assessment procedures depending on the specific environmental conditions. The seeds spilled on the soil surface in spring should be meticulously handled and managed to prevent their unintended effects on the ecosystem. Our study could serve as a useful reference for future studies seeking to develop appropriate research tools to determine factors affecting the invasiveness of transgenic plants used for environmental remediation.

Author Contributions: Conceptualization, K.-H.N.; methodology, K.-H.N. and S.M.H.; formal analysis, K.-H.N. and S.M.H.; investigation, S.M.H.; writing-original draft preparation, K.-H.N. and S.M.H.; writing-review and editing, K.-H.N.; supervision, K.-H.N.; project administration, K.-H.N.; funding acquisition, K.-H.N. All authors have read and agreed to the published version of the manuscript.

Funding: This research was supported by grants from the National Institute of Ecology (NIE), funded by the Ministry of the Environment (MOE) of Korea (NIE-A-2020-04 and NIE-A-2020-10).

Conflicts of Interest: The authors declare no conflict of interest.

\section{References}

1. Key, S.; Ma, J.K.; Drake, P.M. Genetically modified plants and human health. J. R. Soc. Med. 2008, 101, 290-298. [CrossRef]

2. United Nations. Cartagena Protocol on Biosafety to the Convention on Biological Diversity; Secretariat of the Convention on Biological Diversity: Montreal, QC, Canada, 2000.

3. MOTIE. Transboundary Movement, etc. of Living Modified Organisms Act (Act No. 6448 of Mar. 28, 2001, as Amended up to Act No. 15181 of Dec. 12, 2017); Ministry of Trade, Industry and Energy: Sejong-si, Korea, 2017. Available online: https://elaw.klri.re.kr/kor_mobile/viewer.do?hseq=46334\&type=lawname\&key=Transboundary+ Movement\%2C+Etc. +of+Living+Modified+Organisms+Act (accessed on 21 September 2020).

4. Lee, J.R.; Choi, W.; Jo, B.H.; Kim, I.R.; Moon, J.C.; Shin, S.Y.; Seol, M.A.; Eum, S.J.; Song, H.R. Ministry of Environment's Guide to Safety Management of Living Modified Organisms; The Ministry of Environment National Institute of Ecology: Seocheon, Korea, 2015.

5. Nam, K.H.; Han, S.M.; Lee, J.R.; Park, J.H.; Choi, W.; Jung, Y.J.; Kim, D.W.; Lim, H.S.; Yoo, S.H.; Kim, I.R.; et al. Establishment of LMO Risk Assessment System and Operation of the Institute of LMO Risk Assessment under the Jurisdiction of the Ministry of Environment; National Institute of Ecology: Seocheon-gun, Korea, 2019.

6. KBCH. Import and Export Status; Korea Biosafety Clearing House: Daejeon, Korea, 2020; Available online: https://www.biosafety.or.kr/sub/info.do?m=030202\&s=kbch (accessed on 21 September 2020).

7. Kim, C.G.; Yi, H.; Park, S.; Yeon, J.E.; Kim, D.Y.; Kim, D.I.; Lee, K.H.; Lee, T.C.; Paek, I.S.; Yoon, K.W.; et al. Monitoring the occurrence of genetically modified soybean and maize around cultivated fields and at a grain receiving port in Korea. J. Plant Biol. 2006, 49, 218-223. [CrossRef]

8. Lee, B.; Kim, C.G.; Park, J.Y.; Park, K.W.; Kim, H.J.; Yi, H.; Jeong, S.C.; Yoon, W.K.; Kim, H.M. Monitoring the occurrence of genetically modified soybean and maize in cultivated fields and along the transportation routes of the Incheon port in South Korea. Food Control 2009, 20, 250-254. [CrossRef]

9. Park, K.W.; Lee, B.; Kim, C.G.; Kim, D.Y.; Park, J.Y.; Ko, E.M.; Jeong, S.C.; Choi, K.H.; Yoon, W.K.; Kim, H.M. Monitoring the occurrence of genetically modified maize at a grain receiving port and along transportation routes in the Republic of Korea. Food Control 2010, 21, 456-461. [CrossRef]

10. Lee, J.R.; Lim, H.S.; Kim, I.R.; Choi, W.; Park, J.H.; Jung, Y.J.; Kim, D.W.; Eum, S.J.; Seol, M.A.; Hwang, J.E. Study on Environmental Monitoring and Post-Management of LMO; National Institute of Ecology: Seocheon-gun, Korea, 2018.

11. KBCH. Biosafety Vol.18 No.2; Korea Biosafety Clearing House: Daejeon, Korea, 2017.

12. KBCH. Biosafety Vol.18 No.3; Korea Biosafety Clearing House: Daejeon, Korea, 2017. 
13. Conner, A.J.; Glare, T.R.; Nap, J.P. The release of genetically modified crops into the environment. Plant J. 2003, 33, 19-46. [CrossRef] [PubMed]

14. Ammann, K.; Jacot, Y.; Al Mazyad, P.R. Weediness in the light of new transgenic crops and their potential hybrids. J. Plant Dis. Prot. 2000, 17, 19-29.

15. Raybould, A. The bucket and the searchlight: Formulating and testing risk hypotheses about the weediness and invasiveness potential of transgenic crops. Environ. Biosaf. Res. 2010, 9, 123-133. [CrossRef] [PubMed]

16. Moody-Weis, J.; Alexander, H.M. The mechanisms and consequences of seed bank formation in wild sunflowers (Helianthus annuus). J. Ecol. 2007, 95, 851-864. [CrossRef]

17. Warwick, S.I.; Beckie, H.J.; Hall, L.M. Gene flow, invasiveness, and ecological impact of genetically modified crops. Ann. N. Y. Acad. Sci. 2009, 1168, 72-99. [CrossRef]

18. Rajjou, L.; Duval, M.; Gallardo, K.; Catusse, J.; Bally, J.; Job, C.; Job, D. Seed germination and vigor. Annu. Rev. Plant Biol. 2012, 63, 507-533. [CrossRef]

19. Ventura, L.; Donà, M.; Macovei, A.; Carbonera, D.; Buttafava, A.; Mondoni, A.; Rossi, G.; Balestrazzi, A. Understanding the molecular pathways associated with seed vigor. Plant Physiol. Biochem. 2012, 60, $196-206$. [CrossRef] [PubMed]

20. Wu, X.; Ning, F.; Hu, X.; Wang, W. Genetic modification for improving seed vigor is transitioning from model plants to crop plants. Front. Plant Sci. 2017, 8. [CrossRef] [PubMed]

21. Rugh, C.L.; Senecoff, J.F.; Meagher, R.B.; Merkle, S.A. Development of transgenic yellow poplar for mercury phytoremediation. Nat. Biotechnol. 1998, 16, 925-928. [CrossRef] [PubMed]

22. Huysen, T.; Terry, N.; Pilson-Smits, E.A.H. Exploring the selenium phytoremediation potential of transgenic Indian mustard overexpressing ATP sulfurylase or cystathionine- $\gamma$-synthase. Int. J. Phytoremed. 2004, 6, 111-118. [CrossRef] [PubMed]

23. Eapen, S.; D'souza, S.F. Prospects of genetic engineering of plants for phytoremediation of toxic metals. Biotechnol. Adv. 2005, 23, 97-114. [CrossRef]

24. Hussein, H.S.; Ruiz, O.N.; Terry, N.; Daniell, H. Phytoremediation of mercury and organomercurials in chloroplast transgenic plants: Enhanced root uptake, translocation to shoots and volatilization. Environ. Sci. Technol. 2007, 41, 8439-8446. [CrossRef]

25. Peuke, A.D.; Rennenberg, H. Phytoremediation: Molecular biology, requirements for application, environmental protection, public attention and feasibility. EMBO Rep. 2005, 6, 497-501. [CrossRef]

26. Bañuelos, G.; Terry, N.; LeDuc, D.L.; Pilon-Smits, E.A.H.; Markey, B. Field trial of transgenic Indian mustard plants shoes enhanced phytoremediation of selenium-contaminated sediment. Environ. Sci. Technol. 2005, 39, 1771-1777. [CrossRef]

27. Bañuelos, G.; Danika, L.; LeDuc, D.L.; Pilon-Smits, E.A.H.; Terry, N. Transgenic Indian mustard overexpressing selenocysteine lyase or selenocysteine methyltransferase exhibit enhanced potential for selenium phytoremediation under field conditions. Environ. Sci. Technol. 2007, 41, 599-605. [CrossRef]

28. James, C.A.; Xin, G.; Doty, S.L.; Muiznieks, I.; Newman, L.; Strand, S.E. A mass balance study of the phytoremediation of perchloroethylene-contaminated groundwater. Environ. Pollut. 2009, 157, 2564-2569. [CrossRef]

29. Legault, E.K.; James, C.A.; Stewart, K.; Muiznieks, I.; Doty, S.L.; Strand, S.E. A field trail of TCE phytoremediation by genetically modified poplars expressing cytochrome P450 2E1. Environ. Sci. Technol. 2017, 51, 6090-6099. [CrossRef] [PubMed]

30. Hur, M.; Kim, Y.; Song, H.R.; Kim, J.M.; Choi, Y.I.; Yi, H. Effect of genetically modified poplars on soil microbial communities during the phytoremediation of waste mine tailings. Appl. Environ. Microbiol. 2011, 77, 7611-7619. [CrossRef] [PubMed]

31. Shim, D.; Kim, S.; Choi, Y.I.; Song, W.Y.; Park, J.; Youk, E.S.; Jeong, S.C.; Martinoia, E.; Noh, E.W.; Lee, Y. Transgenic poplar trees expressing yeast cadmium factor 1 exhibit the characteristics necessary for the phytoremediation of mine tailing soil. Chemosphere 2013, 90, 1478-1486. [CrossRef] [PubMed]

32. Dushenkov, S.; Vasudev, D.; Kapulnik, Y.; Gleba, D.; Fleisher, D.; Ting, K.C.; Ensley, B. Removal of uranium from water using terrestrial plants. Environ. Sci. Technol. 1997, 31, 3468-3474. [CrossRef]

33. January, M.C.; Cutright, T.J.; Van Keulen, H.; Wei, R. Hydroponic phytoremediation of Cd, Cr, Ni, As, and Fe: Can Helianthus annuus hyperaccumulate multiple heavy metals? Chemosphere 2008, 70, 531-537. [CrossRef] [PubMed] 
34. Prasad, M.N.V. Sunflower (Helinathus annuus L.)—A potential crop for environmental industry. Helia 2007, 30, 167-174.

35. Alexander, H.M.; Schrag, A.M. Role of soil seed banks and newly dispersed seeds in population dynamics of the annual sunflower, Helianthus annuus. J. Ecol. 2003, 91, 987-998. [CrossRef]

36. Fernández-Martínez, J.M.; Pérez-Vich, B.; Velasco, L. Sunflower. In Oil Crops; Vollmann, J., Rajcan, I., Eds.; Springer: New York, NY, USA, 2009; pp. 155-232.

37. Gupta, R.K.; Das, S.K. Physical properties of sunflower seeds. J. Agric. Eng. Res. 1997, 66, 1-8. [CrossRef]

38. ISTA. International Rules for Seed Testing, 2010 ed.; International Seed Testing Association: Bassersdorf, Switzerland, 2010.

39. KMA. Synoptic Weather Observation; Korea Meteorological Administration: Seoul, Korea, 2020; Available online: https://data.kma.go.kr/data/grnd/selectAsosRltmList.do (accessed on 21 September 2020).

40. KMA. Statistics by Condition; Korea Meteorological Administration: Seoul, Korea, 2020; Available online: https://data.kma.go.kr/climate/RankState/selectRankStatisticsDivisionList.do?pgmNo=179 (accessed on 21 September 2020).

41. NIAST. Methods of Soil and Plant Analysis; National Institute of Agricultural Science and Technology: Suwon, Korea, 2000.

42. Mercer, K.L.; Shaw, R.G.; Wyse, D.L. Increased germination of diverse crop-wild hybrid sunflower seeds. Ecol. Appl. 2006, 16, 845-854. [CrossRef]

43. Roberts, E.H. Temperature and seed germination. In Plants and Temperature; Long, S.P., Woodword, F.I., Eds.; Symposia of the Society for Experimental Biology, Company of Biologists: Cambridge, UK, 1988; pp. 109-132.

44. Gay, C.; Corbineau, F.; Côme, D. Effects of temperature and oxygen on seed germination and seedling growth in sunflower (Helianthus annuus L.). Envrion. Exp. Bot. 1991, 31, 193-200. [CrossRef]

45. Bakker, R.M.; Bakker, J.P.; Grandin, U.; Kalamees, R.; Milberg, P.; Poschlod, P.; Thompson, K.; Willems, J.H. Seed size, shape and vertical distribution in the soil: Indicators of seed longevity. Funct. Ecol. 1998, 12, 834-842. [CrossRef]

46. Tanveer, A.; Tasneem, M.; Khaliq, A.; Javaid, M.M.; Chaudhry, M.N. Influence of seed size and ecological factors on the germination and emergence of field bindweed (Convolvulus arvensis). Planta Daninha 2013, 31, 39-51. [CrossRef]

47. Leishman, M.R.; Westoby, M. The role of large seed size in shaded conditions: Experimental evidence. Funct. Ecol. 1994, 8, 205-214. [CrossRef]

48. Khalifa, F.M.; Schneiter, A.A.; El Tayeb, E.I. Temperature-germination responses of sunflower (Helianthus annuus L.) genotypes. Helia 2000, 23, 97-104.

49. Roberts, H.A. Seed banks in soils. Adv. Appl. Biol. 1981, 6, 1-55.

50. Murdoch, A.J.; Ellis, R.H. Dormancy, viability and longevity. In Seeds: The Ecology of Regeneration in Plant Communities, 2nd ed.; Fenner, M., Ed.; CAB International: Wallingford, UK, 2000; pp. 183-214.

51. Traba, J.; Azcárate, F.M.; Peco, B. From what depth do seeds emerge? A soil seed bank experiment with Mediterranean grassland species. Seed Sci. Res. 2004, 14, 297-303. [CrossRef]

52. Vleeshouwers, L.M. Modelling the effect of temperature, soil penetration resistance, burial depth and seed weight on pre-emergence growth of weeds. Ann. Bot. 1997, 79, 553-563. [CrossRef]

53. Benvenuti, S.; Macchia, M.; Miele, S. Quantitative analysis of emergence of seedlings from buried weed seeds with increasing soil depth. Weed Sci. 2001, 49, 528-535. [CrossRef]

54. Pekrun, C.; Hewitt, J.D.J.; Lutman, P.J.W. Cultural control of volunteer oilseed rape (Brassica napus). J. Agric. Sci. 1998, 130, 155-163. [CrossRef]

55. Umurzokov, M.; Jia, W.; Cho, K.M.; Khaitov, B.; Sohn, S.I.; Cho, J.W.; Park, K.W. Persistence, Viability and Emergence Rate of Canola (Brassica napus L) in Korean Soil. Weed Turfgrass Sci. 2019, 8, 309-318.

56. Benvenuti, S.; Macchia, M. Effect of hypoxia on buried weed seed germination. Weed Res. 1995, 35, 343-351. [CrossRef]

57. Karssen, C.M. Environmental conditions and endogenous mechanisms involved in secondary dormancy of seeds. Isr. J. Plant Sci. 1980, 29, 45-64.

58. Gulden, R.H.; Thomas, A.G.; Shirtliffe, S.J. Secondary dormancy, temperature, and burial depth regulate seedbank dynamics in canola. Weed Sci. 2004, 52, 382-388. [CrossRef]

59. Chantre, G.R.; Sabbatini, M.R.; Orioli, G.A. Effect of burial depth and soil water regime on the fate of Lithospermum arvense seeds in relation to burial time. Weed Res. 2009, 49, 81-89. [CrossRef] 
60. Kremer, R.J. Management of weed seed banks with microorganisms. Ecol. Appl. 1993, 3, 42-52. [CrossRef] [PubMed]

61. Nikolić, N.; Squartini, A.; Concheri, G.; Stevanato, P.; Zanin, G.; Masin, R. Weed seed decay in no-till field and planted riparian buffer zone. Plants 2020, 9, 293. [CrossRef]

62. Blaney, C.S.; Kotanen, P.M. Persistence in the seed bank: The effects of fungi and invertebrates on seeds of native and exotic plants. Ecoscience 2002, 9, 509-517. [CrossRef]

63. Wagner, M.; Mitschunas, N. Fungal effects on seed bank persistence and potential applications in weed biocontrol: A review. Basic Appl. Ecol. 2008, 9, 191-203. [CrossRef]

64. Seiwa, K.; Watanabe, A.; Saitoh, T.; Kannu, H.; Akasaka, S. Effects of burying depth and seed size on seedling establishment of Japanese chestnuts, Castanea crenata. For. Ecol. Manag. 2002, 164, 149-156. [CrossRef]

65. Ahmed, T.A.M.; Mutwali, E.M.; Salih, E.A. The Effect of Seed Size and Burial Depth on the Germination, Growth and Yield of Sunflower (Helianthus annus L.). Am. Sci. Res. J. Eng. Technol. Sci. 2019, 53, 75-82.

66. Yanful, M.; Maun, M.A. Effects of burial of seeds and seedlings from different seed sizes on the emergence and growth of Strophostyles helvola. Can. J. Bot. 1996, 74, 1322-1330. [CrossRef]

67. Mtambalika, K.; Munthali, C.; Gondwe, D.; Missanjo, E. Effect of seed size of Afzelia quanzensis on germination and seedling growth. Int. J. For. Res. 2014. [CrossRef]

Publisher's Note: MDPI stays neutral with regard to jurisdictional claims in published maps and institutional affiliations.

(C) 2020 by the authors. Licensee MDPI, Basel, Switzerland. This article is an open access article distributed under the terms and conditions of the Creative Commons Attribution (CC BY) license (http://creativecommons.org/licenses/by/4.0/). 